\title{
PENINGKATAN AKUNTABILITAS YAYASAN MELALUI PENDAMPINGAN PENYUSUNAN LAPORAN KEUANGAN PADA YAYASAN AS-SHOFI DI KEDIRI KABUPATEN LOMBOK BARAT
}

\author{
Baiq Rosyida Dwi Astuti \\ Fakultas Ekonomi Dan Bisnis Universitas Mataram \\ rosyidabaiq@unram.ac.id \\ Iman Waskito \\ Fakultas Ekonomi Dan Bisnis Universitas Mataram \\ waskitoiman@unram.ac.id \\ Ringkasan
}

Yayasan merupakan salah satu bentuk organisasi publik yang menyediakan pelayanan serta mengelola dana sumbangan dari masyarakat luas. Sebagai organisasi milik publik, yayasan juga perlu didorong untuk menerapkan akuntabilitas melalui pengadministrasian dan penyusunan laporan keuangan. Kegiatan ini bertujuan untuk memberikan pemahaman pada pengelola Yayasan AS-Shofi Montong Are Kecamatan Kediri Kabupaten Lombok Barat mengenai pentingnya laporan keuangan dan sekaligus mendampingi pengelola yayasan menyusun laporan keuangan sesuai dengan PSAK 45. Kegiatan ini dilakukan melalui pelatihan dan pendampingan. Pelatihan dilakukan dengan memberikan pemahaman kepada pengurus tentang pentingnya akuntabilitas yayasan, serta membantu menyiapkan berkas-berkas untuk penyusunan laporan keuangan. Dalam tahap pendampingan, Tim PPM membantu yayasan menyusun laporan keuangan berdasarkan bukti transaksi yang dimiliki yayasan.

Kata kunci: laporan keuangan, yayasan 


\section{Jurnal ABDIMAS INDEPENDEN}

Vol. 1, No. 1, Mei 2020

\section{PENDAHULUAN}

\section{Analisis Situasi}

Fenomena yang dapat diamati dalam perkembangan sektor publik adalah semakin meningkatnya tuntutan pelaksanaan akuntabilitas publik oleh organisasi sektor publik seperti halnya yayasan. Tuntutan akuntabilitas ini terkait dengan perlunya transparansi dan pemberian informasi kepada publik dalam rangka memenuhi hak-hak publik. Organisasi nonprofit seperti yayasan ini berbeda dengan organisasi profit, yakni pada sumber daya awal mekanisme organisasi yang diperoleh dari sumbangan. Kreditor dan pemasok membutuhkan pengukuran jumlah, saat dan kepastian arus kas masuk. Sehingga dapat menilai apakah yayasan mampu memberikan jasa secara berkesinambungan (going concern). Dalam tataran pelaksanaan, prinsip-prinsip akuntabilitas harus dapat dibuktikan oleh yayasan (Nainggolan, 2005)

Yayasan harus mampu mengelola jasa serta diinformasikan kepada pihak-pihak yang berkepentingan dalam bentuk laporan keuangan, dimana informasi mengenai aktiva, kewajban, aktiva bersih, dan informasi mengenai hubungan diantara unsur-unsur tersebut disampaikan. Laporan yang disusun tersebut juga harus menyajikan secara terpisah aktiva bersih, baik terikat maupun tidak terikat penggunaannya. Hasil pengelolaan sumber daya yayasan akan dipertanggungjawbakan melalui penyajian laporan aktivitas dan laporan arus kas. Laporan aktivitas akan menjelaskan mengenai perubahan yang terjadi dalam kelompok aktiva bersih. Pengendalian keuangan yayasan juga diperlukan untuk meminimalkan resiko, peningkatan konsistensi dan akurasi sehingga tidak ada kekacauan. Pernyataan Standar Akuntansi (PSAK) 45 merupakan standar acuan yang dapat digunakan yayasan dalam mendesain dan menyusun laporan keuangannya.

Hasil kajian Aldiansyah dan Lambey (2017) menunjukkan bahwa Madrasah Ibtidaiyah yang ditelitinya belum menyusun laporan keuangan. Pihak sekolah menyusun laporan kas umum madrasah, laporan realisasi anggaran dan daftar inventaris yang hanya menyajikan nama aset tanpa ada informasi tentang harga perolehan. Madrasah juga belum mengelompokkan jenis akun, belum melakukan peyusutan dan salah catat dalam buku kas umum. Kesimpulan serupa juga diperoleh Hasunah (2015) dimana 
dinyatakan bahwa yayasan pendidikan islam yang ditelitinya belum menyusun laporan keuangan dan hanya membuat catatan penerimaan dan pengeluaran kas.

Kegiatan pendampingan ini nantinya diharapkan dapat memberikan pemahaman mengenai standar pelaporan keuangan yayasan berdasarkan PSAK 45, sehingga yayasan memiliki informasi yang lebih relevan untuk pengambilan keputusan finansial yang berdampak besar. Selain itu, tersusunnya laporan keuangan menjadi bukti bahwa yayasan berkomitmen untuk menerapkan akuntabilitas.

\section{Perumusan Masalah}

Permasalahan yang dapat diidentifikasikan adalah kurangnya pengetahuan pengelola Yayasan AS-Shofi Montong Are Kecamatan Kediri Kabupaten Lombok Barat dalam penyusunan laporan keuangan. Jadi perumusan masalah dalam pengabdian masyarakat ini adalah bagaimana penyusunan laporan keuangan Yayasan As-Shofi yang sesuai dengan PSAK 45

\section{Tujuan Kegiatan}

Kegiatan ini bertujuan untuk memberikan pemahaman pada pengelola Yayasan AS-Shofi Montong Are Kecamatan Kediri Kabupaten Lombok Barat mengenai pentingnya laporan keuangan dan sekaligus mendampingi pengelola yayasan tersebut dalam menyusun laporan keuangan sesuai dengan PSAK 45

\section{Manfaat Kegiatan}

Kegiatan ini diharapkan dapat meningkatkan pengetahuan dan kemampuan pengelola Yayasan AS-Shofi Montong Are Kecamatan Kediri Kabupaten Lombok Barat dalam menyusun laporan keuangan sesuai dengan PSAK 45.

\section{METODE KEGIATAN}

Metode yang digunakan dalam melaksanakan kegiatan ini adalah pendampingan dalam penyusunan laporan keuangan berupa konsultasi jika terjadi masalah dalam penyusunan laporan keuangan tersebut. Kegiatan yang dilakukan difasilitasi oleh Tim PPM Universitas Mataram melalui prosedur berikut:

a. Tahap 1 (Jangka Waktu 4 bulan) 


\section{Jurnal ABDIMAS INDEPENDEN}

Vol. 1, No. 1, Mei 2020

1. Observasi dan Persiapan (1 bulan)

Observasi dan persiapan dilakukan dalam rangka mempersiapkan segala sesuatunya yang terkait dengan kegiatan pendampingan yang dilakukan, seperti pembuatan modul yang nantinya akan dijadikan panduan oleh pengelola Yayasan AS-Shofi Montong Are Kecamatan Kediri Kabupaten Lombok Barat.

2. Pelatihan (1 bulan)

Pelatihan penyusunan laporan keuangan difasilitasi oleh tim pengabdian pada masyarakat dengan fokus pelatihan pada proses penyusunan laporan keuangan yang dimulai dari mempersiapkan buku-buku yang diperlukan seperti buku penerimaan kas, buku pengeluaran kas dan daftar inventarisasi aset.

3. Pendampingan (2 bulan)

Setelah pelatihan penyusunan laporan keuangan, selanjutnya tim pengabdian pada masyarakat melakukan pendampingan. Pendampingan ini perlu dilakukan untuk memastikan pengelola Yayasan AS-Shofi Montong Are Kecamatan Kediri Kabupaten Lombok Barat dapat menyusun laporan keuangan sendiri, sehingga mereka mampu mengelola keuangan yayasan dengan baik.

b. Tahap 2 (Jangka Waktu 2 bulan)

Pada tahap kedua ini, dilakukan evaluasi atas kegiatan yang telah dilakukan selama 5 bulan sebelumnya dan pembuatan laporan akhir dalam rangka akuntabilitas yayasan.

\section{HASIL DAN PEMBAHASAN}

Kegiatan pengabdian kepada masyarakat ini terdiri dari: 1) observasi, 2) sosialisasi, 3) pelatihan, 4) pendampingan, 5) evaluasi, dan 6) penyusunan laporan.

a. Observasi dan Sosialisasi

Kegiatan observasi dirangkaikan dengan sosialisasi yang dilaksanakan pada bulan Juni 2017. Adapun hasil yang kami peroleh adalah sebagai berikut:

1. Yayasan As-Shofi tidak menyusun laporan keuangan secara periodik. Laporan keuangan disusun sesuai permintaan dari Kementerian Agama dengan mengisi formulir yang terkahir kali dilakukan pada tahun 2012. Jadi, tim pengabdian tidak dapat menampilkan laporan keuangan yayasan.

2. Arsip dokumen yang tidak tertata rapi. 
Yayasan memiliki SMA Islam As-Shofi yang dikepalai oleh Bapak Hamzah Abas, S.PD., M.Pd. SMA Islam As-Shofi secara rutin per tiga bulan menyusun laporan keuangan dana BOS sesuai dengan Petunjuk teknis yang ada.

b. Pelatihan

Pelatihan dilakukan pada bulan Juli 2017. Meskipun yayasan tidak dapat menunjukkan laporan keuangan karena mereka tidak membuatnya, Tim tetap menyampaikan hal-hal yang perlu diperhatikan untuk dillakukan agar akuntabilitas keuangan dapat terwujud. Dengan tidak dibuatnya laporan keuangan, maka dapat dikatakan bahwa yayasan tidak akuntabel. Berbeda dengan SMA Islam yang dimiliki yayasan rutin melaporkan penggunaan dana BOS per tiga bulan. Hal tersebut menunjukkan SMA Islam tersebut akuntabel dalam pengelolaan keuangannya.

c. Pendampingan

Pendampingan dilakukan pada bulan Agustus dan September 2017. Kegiatan pendampingan dilakukan dalam 7 kali pertemuan. Pertemuan pertama, tim pengabdian mengumpulkan dokumen terkait yayasan dan kemudian membantu pengurus mengumpulkan bukti transaksi. Pertemuan kedua sampai ketujuh dilanjutkan dengan melakukan proses akuntansi sampai tersusunnya laporan keuangan.

Berikut foto kegiatan pendampingan yang dilakukan:

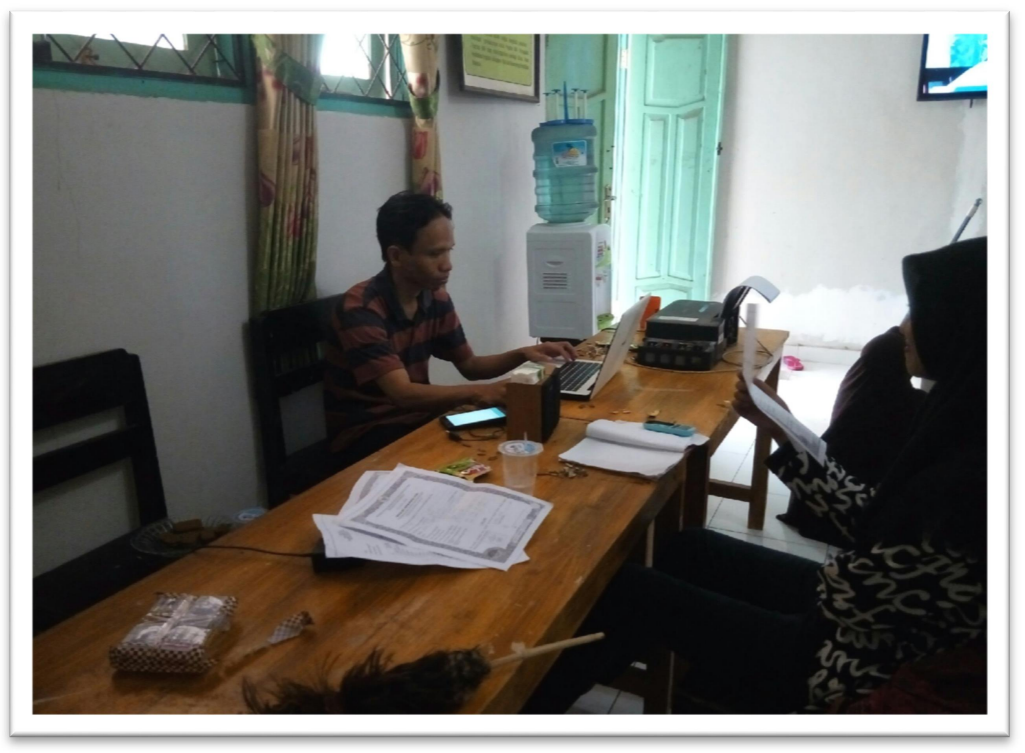

Gambar 1. Pendampingan Penyusunan Laporan Keuangan 


\section{Jurnal ABDIMAS INDEPENDEN}

Vol. 1, No. 1, Mei 2020

d. Evaluasi

Evaluasi dilakukan setelah kegiatan pendampingan selesai pada bulan Oktober dan Nopember 2017. Kegiatan ini dimaksudkan untuk mengevaluasi kegiatan yang telah dilakukan dari observasi sampai dengan kegiatan pendampingan. Hasil evaluasi ini akan disampaikan kepada yayasan dan diuraikan dalam laporan pengabdian kepada masyarakat. Hasil evaluasi yang disampaikan kepada yayasan berupa kelemahankeemahan dalam pengelolaan yayasan secara umum dan kelemahan dalam pengelolaan keuangan secara khusus yang ditemukan selama kegiatan. Pihak yayasan menerima dengan terbuka saran dan rekomendasi yang Tim PPM berikan untuk akuntabilitas yayasan ke depan. Setelah itu Tim PPM diberikan surat keterangan kunjungan oleh yayasan sebagai bukti telah melakukan kegiatan pengabdian kepada masyarakat.

e. Penyusunan Laporan Kegiatan

Penyusunan laporan kegiatan dilakukan pada bulan Nopember setelah Tim PPM melakukan kunjungan ke yayasan untuk menyampaikan evaluasi.

\section{KESIMPULAN DAN SARAN}

\section{Kesimpulan}

Melalui kegiatan ini yayasan memperoleh pengetahuan dan pemahaman dalam penyusunan laporan keuangan serta makna penting dari akuntabilitas laporan keuangan. Dengan bekal pengetahuan dan pemahaman tersebut, diharapkan yayasan dapat mewujudkan akuntabilitas tersebut ke depan.

\section{Saran}

Diperlukan upaya yang berkelanjutan untuk melakukan pendampingan dan mendorong yayasan-yayasan, khususnya pondok pesantren yang tersebar dan banyak berdiri di NTB, agar melakukan pengadministrasian keuangan secara tertib dan menyusun laporan keuangan secara berkala. Hal tersebut akan bermanfaat sebagai dokumen dasar untuk mencari tambahan dana yang berasal dari donatur eksternal, sekaligus upaya untuk mempertanggungjawabkan kinerja yayasan kepada masyarakat luas.

\section{DAFTAR PUSTAKA}


Aldiansyah, Linda Lambey, 2017, Penerapan PSAK no 45 Revisi Tahun 2015 Pada Yayasan Madrasah Ibtidaiyah Baitul Makmur Kota Kotamobagu, Jurnal Accountability Vol 06 No 01 2017. https://media.neliti.com.

Hasunah, 2015, Penyusunan Laporan Keuangan Yayasan Pendidikan Islam Menurut PSAK 45, Skripsi Universitas Jember, www.repository.unej.ac.id

Nainggolan, Pahala, 2005, Akuntansi Keuangan Yayasan dan Lembaga Nirlaba Sejenis, Raja Grafindo Persada, Jakarta

Pernyataan Standar Akuntansi Keuangan (PSAK) nomor 45 Tentang Pelaporan Keuangan Entitas Nirlaba 